\title{
Sanksi Pidana Terhadap Perbuatan Menggunakan Hak Pilih Orang Lain dalam Undang-Undang Pemilu dan Pemilukada
}

\section{Criminal Sanction on Cheating of Persons' Rights in General Election and Head Election}

\author{
Sartono \\ Kepolisian Republik Indonesia \\ E-mail: sartonopascasarjanauho@gmail.com \\ Sabrina Hidayat \\ Pascasarjana Universitas Halu Oleo \\ E-mail: sabrina.hidayat54@yahoo.com \\ Oheo K. Haris \\ Pascasarjana Universitas Halu Oleo \\ E-mail:oheokh@gmail.com
}

\begin{abstract}
This study aims to determine the difference in severity of sanctions in the Election Law and the Election Law on the act of exercising the right to vote for others and the criminal law policy in the Election Law regarding the act of ordering someone to use another person's right to vote. The results of this study indicate that (1) the provisions of criminal acts in the Pilkada Law on criminal sanctions against the use of voting rights of others have been regulated at a minimum, both imprisonment and fines, this is different from the criminal sanctions on the use of the voting rights of others in the Law. -The Election Law only regulates the maximum criminal sanctions, both imprisonment and criminal sanctions, and the fines are relatively lighter when compared to the Pilkada Law and (2) the Criminal Law Policy in the Election Law regarding Acts of ordering someone to use another person's voting rights, i.e. Regulations related to election crimes that regulate the act of ordering people who are not entitled to vote to use other people's voting rights, thus opening up space for election participants to commit these acts but legal proceedings cannot be carried out let alone subject to election criminal sanctions because election criminal acts can only be me reach out to someone who exerts another's suffrage. As a result of the legal vacuum regulating the actions of those who order to use other people's voting rights, it can provide space for election participants and other parties to instruct someone to use other people's voting rights with the aim of obtaining personal gain or for re-voting.Keywords: Minimal Criminal Disparity, Election Law and Head Election.
\end{abstract}

Keyword: Sanction; Election; District Head.

Abstrak: Penelitian ini bertujuan untuk mengetahui perbedaan berat sanksi dalam Undang-Undang Pemilu dan Undang-Undang Pemilukada terhadap perbuatan 
menggunakan hak pilih orang lain dan kebijakan hukum pidana dalam Undang-Undang Pemilu terkait perbuatan menyuruh seseorang menggunakan hak pilih orang lain. Hasil penelitian ini menunjukkan bahwa (1) Ketentuan tindak pidana dalam Undang-Undang Pilkada tentang sanksi pidana terhadap penggunaan hak pilih orang lain telah diatur maksimal-minimal baik pidana penjara maupun pidana denda hal ini berbeda dengan pengaturan sanksi pidana penggunaan hak pilih orang lain dalam Undang-Undang Pemilu hanya mengatur sanksi pidana maksimal baik sanksi pidana penjara maupun sanksi pidana denda itu pun relatif lebih ringan jika dibanding Undang-Undang Pilkada dan (2) Kebijakan Hukum Pidana dalam Undang-Undang Pemilu terkait Perbuatan menyuruh seseorang menggunakan hak pilih orang lain yaitu tidak terdapat pengaturan terkait tindak pidana pemilu yang mengatur tentang perbuatan menyuruh orang yang tidak berhak memilih untuk memilih menggunakan hak pilih orang lain, sehingga membuka ruang bagi peserta pemilu untuk melakukan perbuatan tersebut namun tidak dapat dilakukan proses hukum apalagi dikenai sanksi pidana pemilu karena tindak pidana pemilu hanya dapat menjangkau terhadap seseorang yang menggunakan hak pilih orang lain. Akibat adanya kekosongan hukum yang mengatur tentang perbuatan orang yang menyuruh menggunakan hak pilih orang lain tersebut, dapat memberikan ruang kepada peserta pemilu maupun pihak lain untuk menyuruh seseorang menggunakan hak pilih orang lain dengan tujuan untuk mendapatkan keuntungan pribadi maupun agar terjadi Pemungutan Suara Ulang.

Kata kunci: Sanksi; Pemilihan; Kepala Daerah.

\section{PENDAHULUAN}

Pemilihan kepala daerah secara langsung menjadi bagian dari proses reformasi ketatanegaraan dan mekanisme demokrasi yang terjadi di Indonesia. Amandemen UUD 1945 yang mengandung spirit pengembalian kedaulatan rakyat dijabarkan dalam wujud pemberian hak-hak politik secara langsung sebagaimana termanifestasi dalam sistem pemilihan presiden dan pemilihan kepala daerah secara langsung. Hasil amandemen UUD 1945 Pasal 18 ayat (4) yang berbunyi: Gubernur, Bupati dan Walikota masing-masing Kepala Pemerintah Daerah Provinsi, Kabupaten dan Kota dipilih secara demokratis.

Pemilu bisa berjalan demokratis jika ada pengawasan yang dilakukan secara terbuka jujur dan adil. Untuk menciptakan pemilu yang bersih diperlukan pengawasan yang efektif. Efektivitas pengawasan pemilu ditentukan oleh para pengawas dalam memahami dan mengerti bagaimana proses pengawasan itu dijalankan dengan baik. Dengan demikian, Panwaslu merupakan pilar inti dalam penyelenggaraan Pemilu, karena Pemilu yang jujur, adil, dan demokratis, sangat tergantung pada sejauh mana Panwaslu bekerja dengan baik dan menjamin hak-hak pemilih berlangsung dan demokratis.

Kondisi banyaknya produk legislatif bermasalah, tentunya sangat mengganggu upaya penegakan hukum tindak pidana”. Belum lagi faktanya, secara keilmuan berbagai istilah hukum ditandai oleh silang pendapat. Misalnya, istilah tindak pidana belum ada 
kesatuan pendapat. Moeljatno mengatakan, bahwa: "perbuatan pidana itu dapat dipersamakan dengan criminal act, jadi berbeda dengan strafbaar feit, yang meliputi pula pertanggungjawaban pidana. Hukum Pidana tidak melarang orang mati, tetapi melarang adanya orang mati, karena perbuatan orang lain. Criminal act itu berarti kelakuan dan akibat yang disebut juga actus reus." 1 Seiring dengan euforia demokrasi pasca reformasi, maka kebijakan politik hukum yang berkaitan dengan Pemilu mengalami perkembangan yang sangat pesat, salah satu bentuknya, adalah produk legislatif tentang pelaksanaan pemilihan wakil rakyat dan pejabat pemerintah secara langsung yaitu UU Pemilu/Pilkada. Ketika pengertian tindak pidana dihubungkan dengan istilah Pemilihan Umum, tentu persoalannya menjadi semakin kompleks.

Menurut Topo Santoso dari sudut politik hukum (criminal policy), kita melihat terjadinya perkembangan dalam tindak pidana Pemilu. Perkembangan itu mencakup semakin luasnya cakupan tindak pidana pemilu, peningkatan jenis tindak pidana dan peningkatan sanksi pidana. Meskipun ketentuan mengenai tindak pidana pemilu, sudah ada sejak kemerdekaan di dalam KUHP yang diberlakukan dengan UU No. 1 Tahun 1946, dan telah diatur pula dalam sejumlah perundang-undangan tentang Pemilu Orde Baru ${ }^{2}$ Namun perkembangan politik hukum pasca reformasi, menimbulkan perubahan sistem penyelenggaraan Pemilu dari tidak langsung menjadi Pemilu secara langsung dan sekarang diselenggarakan secara serentak masif, terstruktur dan terorganisir. Satu di antara wujud dan mekanisme demokrasi pelaksanaan Pemilu serentak, adalah banyak terealisasi produk legislatif Pemilu terkait sistematika pelaksanaan Pemilu.

Sebagai sarana untuk mewujudkan ketertiban yang berkeadilan, kaidah-kaidah hukum dirumuskan dalam bentuk aturan-aturan hukum tertulis yang disebut perundangundangan. Secara tradisional dalam buku- buku hukum pidana dilihat, bahwa hukum pidana itu dibagi atas hukum pidana umum ialah KUHP (lex generali), dan hukum pidana khusus yang tercantum di dalam perundang-undangan dan di luar KUHP di Indonesia (lex spesialis), seperti hukum pidana administrasi (administrative penal law). ${ }^{3}$ Pada prinsipnya tujuan utama semua bagian hukum ialah menjaga ketertiban, ketenangan, kesejahteraan dan kedamaian dalam masyarakat, tanpa dengan sengaja menimbulkan penderitaan. Van Bemmelen, berpendapat bahwa "hukum pidana itu merupakan ultimum remedium (upaya

\footnotetext{
1 Moeljatno dalam Andi Hamzah, Hukum Pidana Indonesia \& Perkembangannya, Jakarta: PT Sofmedia, 2015, hlm. 118-119.

2 Topo Santoso, Tindak Pidana Pemilu, Jakarta: Sinar Grafika, 2006, hlm. 151.

3 Ibid., hlm. 15-17.
} 
terakhir). Sedapat mungkin dibatasi, artinya kalau bagian lain dari hukum itu tidak cukup untuk menegakkan norma-norma yang diakui oleh hukum, barulah hukum pidana diterapkan"4.

Meskipun hukum pidana itu merupakan umtimum remedium (upaya terakhir) termasuk dalam penegakan hukum pemilihan dan pemilu, namun dalam pengaturannya juga terdapat kontroversi khususnya terkait pengaturan sanksi tindak pidana pemilihan maupun pemilu. Dalam ketentuan tindak pidana pemilihan Gubernur, Bupati dan/atau Walikota yang telah diubah beberapa kali, terakhir diubah dengan Undang-Undang Nomor 10 Tahun 2016 terlihat jelas dalam pengaturan sanksi pidana mengatur maksimal dan minimal termasuk pidana denda namun dalam ketentuan tindak pidana Pemilu sebagaimana dimaksud dalam Undang-Undang Nomor 7 Tahun 2017 hanya mengatur sanksi maksimal termasuk denda, itu pun relatif sangat ringan jika dibanding pengaturan sanksi Tindak Pidana Pemilihan terhadap perbuatan yang sesungguhnya sama antara keduanya.

Salah satunya adalah pengaturan terkait sanksi tindak pidana berupa "setiap orang dengan sengaja pada saat pemungutan suara mengaku dirinya sebagai orang lain". Dalam ketentuan Pasal 178 A Undang-Undang Nomor 10 Tahun 2016 tentang Pemilihan Gubernur, Bupati dan/atau Walikota disebutkan bahwa:

Setiap orang yang pada waktu pemungutan suara dengan sengaja melakukan perbuatan melawan hukum mengaku dirinya sebagai orang lain untuk menggunakan hak pilih, dipidana dengan pidana penjara paling singkat 24 (dua puluh empat) bulan dan paling lama 72 (tujuh puluh dua) bulan dan denda paling sedikit Rp. 24.000.000,00 (dua puluh empat juta rupiah) dan paling banyak Rp. 72.000.000,00 (tujuh puluh dua juta rupiah).

Sementara dalam ketentuan Pasal 533 Undang-undang Nomor 7 Tahun 2017 tentang Pemilihan Umum menyatakan bahwa :

Setiap orang yang dengan sengaja pada saat pemungutan suara mengaku dirinya sebagai orang lain dan/atau memberikan suaranya lebih dari 1 (satu) kali di 1 (satu) TPS atau lebih dipidana dengan pidana penjara paling lama 1 (satu) tahun 6 (enam) bulan dan denda paling banyak Rp. 48.000.000,00 (empat puluh delapan juta rupiah).

Memperhatikan kedua pengaturan di atas, terlihat jelas adanya disparitas terkait ketentuan sanksi pidana. Meskipun dalam konteks yang berbeda antara Pemilihan dan Pemilu juga pengaturan yang berbeda yaitu Undang-Undang Nomor 10 Tahun 2016 dan Undang-Undang Nomor 7 Tahun 2017, namun perbuatan tindak pidana cenderung sama.

4 Van Bemmelen dalam Andi Hamzah, Op. cit., hlm. 12. 
Perbedaan tingkat sanksi pidana dimaksud juga sangat berpengaruh terhadap Putusan Pengadilan dalam pemberian sanksi pidana penjara dan denda antara tindak pidana yang sama dalam Pemilihan maupun Pemilu.

Sebagai contoh yang penulis angkat sebagai objek penelitian ini adalah kasus yang terjadi pada tahun 2017 yaitu Putusan Pengadilan Negeri Provinsi Sulawesi Tenggara Nomor: 53/PID.SUS/2017/PT SULTRA dimana telah terjadi tindak pidana dengan terdakwa Jefri Alias Jhejher terbukti secara sah dan meyakinkan bersalah melakukan tindak pidana "dengan sengaja melakukan perbuatan melawan hukum mengaku dirinya sebagai orang lain untuk menggunakan hak pilih" dalam dakwaan melanggar Pasal 178 A No. 10 tahun 2016 tentang perubahan kedua atas Undang-Undang Nomor 01 Tahun 2015 Tentang Penetapan Peraturan Pemerintah Pengganti Undang-Undang Nomor 01 tahun 2014 tentang pemilihan Gubernur, Bupati dan Walikota Menjadi Undang-Undang dengan penjatuhan pidana penjara selama 24 (dua puluh empat bulan) dan denda sebanyak Rp 24. 000.000,- (dua puluh empat juta rupiah) subsider 1 (satu) bulan kurungan. Pada tahun 2019 Putusan Pengadilan Negeri Kota Kendari Nomor: 296/Pid.Sus/2019/PN/Kdi telah terjadi tindak pidana dengan terdakwa Syahir telah terbukti secara sah dan meyakinkan bersalah melakukan tindak pidana secara bersama-sama "setiap orang dengan sengaja pada saat pemungutan suara mengaku dirinya sebagai orang lain", sebagaimana tercantum dalam Dakwaan Pasal 533 UU No. 7 Tahun 2017 tentang pemilu dengan penjatuhan pidana penjara selama 2 (dua) bulan dan denda Rp. 1.000.000,- (Satu Juta Rupiah) Subsider 2 (dua) bulan kurungan.

\section{METODE PENELITIAN}

Metode penelitian yang digunakan dalam penelitian ini adalah hukum normatif, dimana penelitian hukum normatif adalah penelitian hukum yang meletakkan hukum sebagai sebuah bangunan sistem norma ${ }^{5}$, sehingga metode yang digunakan adalah metode deskriptif kualitatif, yaitu mencari dan mengumpulkan data yang ada hubungannya dengan obyek dan permasalahan yang diteliti, kemudian diambil dan disusun secara sistematis untuk mendapatkan gambaran yang jelas dan lengkap mengenai permasalahan yang dibahas.

Mukti Fajar dan Yulianto Achmad, Dualisme Penelitian Hukum Normatif dan Empiris, Yogyakarta: Pustaka Pelajar, 2010, hlm. 33. 


\section{ANALISIS DAN PEMBAHASAN}

\section{Dasar Perbedaan Berat Sanksi dalam Undang-Undang Pemilu dan Undang-Undang Pemilukada terhadap Perbuatan Menggunakan Hak Pilih Orang Lain}

Dasar hukum maupun keberlakuannya menyimpang dari ketentuan umum buku 1 KUHP, bahkan terhadap ketentuan hukum acara (hukum formal), peraturan perundangundangan tindak pidana khusus dapat pula menyimpang dari Kitab Undang-Undang Hukum Acara Pidana (KUHAP). Dibentuknya UU Pemilu/Pilkada ini oleh legislator, berdasarkan pandangan dari doktrin Juridische Specialitiet atau Systematiche Specialiteit yang dikemukakan Ch.J. Enschede tersebut, sehingga pada Undang-Undang Pemilu/Pilkada "melekat" sifat "kekhususan suatu ketentuan pidana", dengan suatu harapan mampu memberikan jaminan kepastian hukum, sekaligus menjawab kebuntuankebuntuan yang lahir dari fenomena hukum terkait election offences; yaitu semua pelanggaran/kejahatan yang berkaitan dengan pemilu yang diatur dalam undang-undang, yang berkaitan dengan penyelenggaraan pemilu, dan semua pelanggaran/kejahatan yang terjadi pada tahapan pemilu. ${ }^{6}$

Pemilihan umum legislatif apabila dikaitkan dengan pengertian mengenai tindak pidana pemilihan umum legislatif itu sendiri tidaklah memiliki pengertian yang tetap yang diatur di dalam peraturan perundang-undangan. Namun dalam pengaturannya terdapat beberapa pasal yang substansinya berkaitan dengan tindak pidana pemilihan umum legislatif. Walaupun hal tersebut tidak disebutkan secara akurat bahwa pasal-pasal tersebut mengenai tindak pidana pemilihan umum legislatif.

Perbuatan mengaku dirinya sebagai orang lain dalam pemungutan suara pada pemilihan umum legislatif diatur pada Pasal 310 Undang-Undang Nomor 8 Tahun 2012 Tentang Pemilihan Umum Anggota Dewan Perwakilan Rakyat, Dewan Perwakilan Daerah, dan Dewan Perwakilan Rakyat Daerah Provinsi, Dewan Perwakilan Rakyat Daerah Kabupaten/Kota. Ketentuan pidana yang dirumuskan dalam pasal tersebut menyatakan:

"Setiap orang yang dengan sengaja pada saat pemungutan suara mengaku dirinya sebagai orang lain dan/atau memberikan suaranya lebih dari 1 (satu) kali di 1 (satu) TPS atau lebih dipidana dengan pidana penjara paling lama 1 (satu) tahun 6 (enam) bulan dan denda paling banyak Rp.18.000.000, (delapan belas juta rupiah)".7

6 Paramita Ersan dan Anna Erliyana, "Kualifikasi Hukum Pidana Khusus Terhadap Tindak Pidana Pemilu/Pilkada (Tinjauan Hukum Administrasi Negara)“, Pakuan Law Review, Volume IV, Nomor 1, Januari-Juni 2018, hlm 13

7 Undang-Undang Republik Indonesia Nomor 8 Tahun 2012 tentang Pemilihan Umum Anggota DPR, DPD, dan DPRD, Bab XXII, Pasal 310. 
Sanksi pidana Undang-Undang Pemilukada dengan mengaku dirinya sebagai orang lain dalam pemungutan suara, tertuang pada Pasal $178 \mathrm{C}$ ayat (2), Undang-Undang Republik Indonesia Nomor 10 Tahun 2016 tentang perubahan Kedua atas UndangUndang Nomor 1 Tahun 2015, Undang-Undang Republik Indonesia Nomor 48 Tahun 2009, Undang-Undang Republik Indonesia Nomor 49 tahun 2009 tentang perubahan Kedua atas Undang-Undang Republik Indonesia Nomor 2 Tahun 1986.

Berdasarkan Undang-Undang Pemilukada terkait tindak pidana jelas mengatur orang yang menyuruh serta orang menggunakan hak pilih orang lain bahwa antara para pembuat dengan pemuat pembantu adalah para pembuat (dader) secara langsung turut serta dalam pelaksanaan tindak pidana, sedangkan pembuat pembantu hanya memberi bantuan yang sedikit atau banyak manfaat dalam melaksanakan tindak pidana. Pembuat yang dimaksud dalam Pasal 55 ayat (1) adalah ia tidak melakukan tindak pidana secara pribadi, melainkan secara Bersama-sama dengan orang lain dalam mewujudkan tindak pidana. Apabila dilihat dari perbuatan masing-masing peserta berdiri sendiri, tetapi hanya memenuhi sebagian unsur tindak pidana. Dengan demikian semua unsur tindak pidana terpenuhi tidak oleh perbuatan satu peserta, tetapi oleh rangkaian semua peserta. Mereka yang melakukan (pembuat pelaksana: pleger) adalah orang yang melakukan sendiri suatu perbuatan yang memenuhi semua unsur delik. Perbedaan dengan dader adalah pleger dalam melakukan tindak pidana masih diperlukan keterlibatan orang lain minimal 1 orang, misalnya pembuat peserta, pembuat pembantu, atau pembuat penganjur. Dalam tindak pidana formal pleger-nya adalah siapa yang melakukan dan menyelesaikan perbuatan terlarang yang dirumuskan dalam tindak pidana yang bersangkutan. Dalam tindak pidana material, pleger-nya adalah orang yang perbuatannya menimbulkan akibat yang dilarang oleh Undang-Undang. ${ }^{8}$

Berdasarkan hal tersebut di atas berbeda halnya dengan Undang-Undang pemilu tidak mengatur ketentuan mengenai sanksi pidana terhadap orang yang menyuruh orang lain untuk memilih dengan menggunakan hak pilih orang lain. Hal demikian terjadi disebabkan adanya problem politik hukum pembentukan Undang-Undang pemilu. Celah

8 Azhar Ridhanie, “Strategi Pengawas Pemilu dalam Menangani Tindak Pidana Pemilu: Implementasi Hukum Progresif dan Penerapan Pasal 55 KUHP dalam Penanganan Perkara Pidana di Kalimantan Selatan", Bawaslu Kalimantan Selatan, http://kalsel.bawaslu.go.id/elibrary/strategi-pengawas-pemilu-dalammenangani-tindak-pidana-pemilu/, diakses pada tanggal 23 Februari 2021. Lihat juga Adami Chazawi, Percobaan dan Penyertaan dalam Hukum Pidana (Pelajaran Hukum Pidana Bagian 3), Jakarta: Raja Grafindo Persada, 1999, hlm. 79. 
yang hari ini ada dalam Undang-Undang Pemilu bisa diprediksi karena bobot UndangUndang Pemilu yang syarat kepentingan politik. Porsi pembahasan lebih banyak difokuskan pada substansi yang berhubungan langsung dengan kepentingan anggota DPR. Materi desain penegakan hukum pemilu, sebaliknya, tidak mendapatkan porsi yang cukup besar dalam pembahasan. Alhasil, sesuai pendapat tersebut, substansi Undang-Undang Pemilu terkait penegakan hukum tidak sesuai harapan.

\section{Kebijakan Hukum Pidana dalam Undang-Undang Pemilu Terkait Perbuatan Menyuruh Seseorang Menggunakan Hak Pilih Orang Lain}

Sebagai bagian dari rezim hukum pidana, mekanisme peradilan pidana pemilu juga mengikuti sistem peradilan pidana secara umum. Dalam sistem peradilan pidana, terjalin sebuah kerangka jaringan sistem peradilan yang mendayagunakan hukum pidana (hukum pidana materiil, hukum pidana formal dan hukum pelaksanaan pidana). Secara terintegrasi dalam kerangka itu, semua unsur sub sistem penegakan hukum yang terdiri dari kepolisian, kejaksaan, pengadilan dan lembaga pemasyarakatan terlibat dalam satu jaringan kerja yang saling berkaitan satu sama lain. ${ }^{9}$

Pertanggungjawaban menurut Mahmud Muladi dan Ferri Antoni Sunarki adalah sebagai berikut:

a. Pertanggungjawaban Pidana adalah Kesalahan yang terdapat dalam jiwa pelaku dalam hubungannya dengan kelakuan yang dapat dipidana. Berdasarkan kewajiban pelaku dapat dicela karena kelakuannya. Kesalahan ditempatkan pada faktor yang menentukan dalam pertanggungjawaban pidana dan tidak hanya dipegang sekedar unsur mental dalam tindak pidana.

b. Pertanggungjawaban Pidana adalah Diteruskannya celaan yang obyektif yang ada pada tindak pidana, untuk dapat dipidananya si pelaku, diisyaratkan bahwa tindak pidana yang dilakukan itu haruslah memenuhi unsur-unsur yang telah ditentukan oleh undang-undang. ${ }^{10}$

Berdasarkan hal di atas, kebijakan hukum pidana terkandung di dalamnya tiga kekuasaan/kewenangan, yaitu kekuasaan legislatif/formulatif berwenang dalam hal

9 Sarah Bambang, Sri Setyadji dan Aref Darmawan, "Penanganan Tindak Pidana Pemilu dalam Sentra Penegakkan Hukum Terpadu (Gakkumdu)", Jurnal Indonesia Sosial Teknologi, Vol. 2, No. 2, Februari 2021, hlm. 284.

10 Mahmud Muladi dan Ferri Antoni Surbakti, Politik Hukum Pidana Terhadap Kejahatan Koporasi, Jakarta: Soft Media, 2010, hlm. 55. 
menetapkan atau merumuskan perbuatan apa yang dapat dipidana yang berorientasi pada permasalahan pokok dalam hukum pidana meliputi perbuatan yang bersifat melawan hukum, kesalahan/pertanggungjawaban pidana dan sanksi apa yang dapat dikenakan oleh pembuat undang-undang. ${ }^{11}$ Tahap aplikasi merupakan kekuasaan dalam hal menerapkan hukum pidana oleh aparat penegak hukum atau pengadilan, dan tahapan eksekutif/administratif dalam melaksanakan hukum pidana oleh aparat pelaksana/eksekusi pidana. ${ }^{12}$

Masalah kebijakan penegakan hukum pidana pemilu setidaknya dapat diisi dengan melihat masing-masing komponen dalam sistem hukum yang secara langsung berpengaruh terhadap penegakan hukum. Lawrence M. Friedman menilai, berhasil atau tidaknya hukum ditegakkan tergantung pada tiga komponen sistem hukum. Pertama, substansi hukum (legal substance). Substansi hukum adalah aturan, norma, dan pola perilaku nyata manusia yang berada dalam sistem itu. ${ }^{13}$ Kedua, struktur atau struktur sistem hukum. Friedman menyebutnya sebagai kerangka atau rangka atau bagian yang tetap bertahan atau bagian yang memberi semacam bentuk dan batasan terhadap keseluruhan. Keberadaan struktur hukum sangat penting, karena betapa pun bagusnya norma hukum, namun jika tidak ditopang aparat penegak hukum yang baik, penegakan hukum dan keadilan hanya sia-sia. Ketiga, budaya hukum (legal culture). Kultur hukum adalah opini-opini, kepercayaan-kepercayaan (keyakinan-keyakinan), kebiasaankebiasaan, cara berpikir, dan cara bertindak, baik dari para penegak hukum maupun dari warga masyarakat tentang hukum dan berbagai fenomena yang berkaitan dengan hukum. ${ }^{14}$

Berangkat dari tiga indikator tersebut, belum efektifnya penegakan hukum pidana pemilu juga tidak dapat dilepaskan dari masalah yang terdapat dalam peraturan perundang-undangan pemilu, khususnya terkait tindak pidana pemilu; masalah profesionalisme aparat penegakan hukum. Pada taraf norma, peraturan perundangundangan sebagaimana diulas pada bagian sebelumnya belum cukup jelas dan lengkap

11 Ibrahim Nainggolan, "Pertanggungjawaban Pidana Perbuatan Penggunaan Merek yang Sama pada Pokoknya Tanpa Izin (Analisis Putusan MA.RI No. 203/Pid.Sus/2015)”, Jurnal EduTech, Volume 5, Nomor 1, Maret 2019, hlm. 32

12 Barda Nawawi Arif, Masalah Penegakan Hukum dan Kebijakan Hukum Pidana dalam Penanggulangan Kejahatan, Jakarta: Kencana Media Group, 2007, hlm. 78-79.

13 Lawrence M. Friedman, American Law: An Introduction, Second Edition, Penerjemah: Wishnu Basuki, Jakarta: PT. Tatanusa, 2001, hlm. 7

14 Ibid. 
mengatur hukum material maupun hukum formal. Bahkan hukum formal yang ada tidak cukup memadai untuk menegakkan hukum pidana pemilu secara efektif. Sementara pada level struktur, penegak hukum dihadapkan pada persoalan masih belum memadainya pemahaman aparatur terhadap jenis tindak pidana pemilu; belum profesional dan masih terjadinya "tolak-menolak" yang berujung pada kebuntuan dalam menangani perkara pidana pemilu. ${ }^{15}$

Sedangkan pada ranah budaya hukum, pihak-pihak berkepentingan, terutama peserta pemilu masih berkecenderungan untuk "mengakali" aturan yang ada sehingga dapat berkelit dari tuntutan hukum. Masyarakat politik bukannya membangun kesadaran akan perlunya mengikuti pemilu sesuai aturan-aturan yang ada, melainkan justru membangun sikap culas atas aturan yang ada. Tiga persoalan penegakan hukum pidana pemilu tersebut berkelindan sedemikian rupa sehingga penegakan hukum pemilu benarbenar lumpuh (sekedar tidak mengatakan mati suri). Akibatnya, perkara-perkara dugaan tindak pidana pemilu pun tidak tertangani dengan baik. ${ }^{16}$

Sistem penanganan tindak pidana pemilu masih membutuhkan pembenahan agar dapat diterapkan dengan baik dan efektif untuk menjadi salah satu instrumen mewujudkan pemilu yang jujur dan adil. Perbaikan sistem penanganan meliputi perbaikan regulasi; penguatan kapasitas dan profesionalisme penegak hukum pemilu; dan peningkatan kesadaran hukum seluruh pemangku kepentingan pemilu. Tanpa melakukan itu, sistem penanganan tindak pidana pemilu akan selalu jalan di tempat dan tidak akan berhasil guna dalam menopang perwujudan pemilu yang jujur dan adil. ${ }^{17}$

Dalam konteks Pemilu yang termasuk dalam sub substansi adalah Pancasila, UUD 1945, perangkat Undang-Undang yang berkaitan dengan Pemilu yaitu Undang-Undang Pemilu Presiden dan Wakil Presiden, Undang-Undang Pemilu Legislatif, Undang-Undang Penyelenggara Pemilu, Undang-Undang Pemerintah Daerah, Undang-Undang Partai Politik, serta peraturan lainnya yang terkait dengan soal Pemilu.

Substansi hukum dapat dikatakan sebagai salah satu faktor yang memberikan kontribusi terhadap banyaknya kasus tindak pidana pemilu. Banyak kasus tindak pidana Pemilu terjadi karena lemahnya sub sistem hukum substansi. Lemahnya sub sistem

15 Khairul Fahmi, “Sistem Penanganan Tindak Pidana Pemilu”, Jurnal Konstitusi, Volume 12, Nomor 2, Juni 2015, hlm. 282.

16 Sarah Bambang, Sri Setyadji dan Aref Darmawan, Op. cit., hlm. 282.

17 Ibid., hlm 283. 
hukum substansi bisa karena disengaja ataupun tidak disengaja. Sub sistem hukum substansi lemah karena sengaja dilemahkan untuk kepentingan politik tertentu. ${ }^{18}$

Undang-Undang Pemilu tidak ada pasal yang mengatur tentang perbuatan orang lain yang menyuruh orang lain menggunakan hak pilih orang lain, sehingga membuka ruang bagi peserta pemilu untuk melakukan perbuatan yang melanggar ketentuan pidana yang terdapat dalam Undang-Undang pemilu, akibat adanya kekosongan hukum yang mengatur tentang perbuatan orang yang menyuruh menggunakan hak pilih orang lain. Dalam hal ini orang yang menyuruh menggunakan hak pilih orang lain, bisa saja memberikan ruang kepada orang yang disuruh menggunakan hak pilih orang lain atau orang yang menyuruh mendapatkan keuntungan.

\section{KESIMPULAN}

Ketentuan tindak pidana dalam Undang-Undang Pilkada tentang sanksi pidana terhadap penggunaan hak pilih orang lain telah diatur maksimal-minimal baik pidana penjara maupun pidana denda hal ini berbeda dengan pengaturan sanksi pidana penggunaan hak pilih orang lain dalam Undang-Undang Pemilu hanya mengatur sanksi pidana maksimal baik sanksi pidana penjara maupun sanksi pidana denda itu pun relatif lebih ringan jika dibanding Undang-Undang Pilkada. Hal inilah yang menjadi dasar pembeda dalam putusan Majelis hakim terkait tindak pidana penggunaan hak pilih orang lain yang terjadi antara Pilkada dan Pemilu walaupun substansi perbuatannya sesungguhnya sama. Selain itu, dalam pengaturan Tindak Pidana Pilkada selain seseorang yang menggunakan hak pilih orang juga dipidana secara bersamasama terhadap seseorang yang menyuruh orang yang tidak berhak memilih menggunakan hak pilih orang lain sementara dalam Undang-Undang Pemilu yang dapat dikenai sanksi Pidana hanya seseorang yang menggunakan hak pilih orang lain. Kebijakan Hukum Pidana dalam Undang-Undang Pemilu terkait Perbuatan menyuruh seseorang menggunakan hak pilih orang lain yaitu tidak terdapat pengaturan terkait tindak pidana pemilu yang mengatur tentang perbuatan menyuruh orang yang tidak berhak memilih untuk memilih menggunakan hak pilih orang lain, sehingga membuka ruang bagi peserta pemilu untuk melakukan perbuatan tersebut namun tidak dapat dilakukan proses hukum apalagi dikenai sanksi pidana pemilu karena tindak pidana pemilu hanya dapat menjangkau terhadap seseorang yang menggunakan hak pilih orang

18 Desmond J. Mahesa, “Mengurai Belantara Penegakan Hukum Pidana Pemilu di Indonesia”, LawJustice.com, https://www.law-justice.co/artikel/77571/mengurai-belantara-penegakan-hukum-pidana-pemilu-diindonesia/, diakses pada tanggal 23 Februari 2021. 
lain. Akibat adanya kekosongan hukum yang mengatur tentang perbuatan orang yang menyuruh menggunakan hak pilih orang lain tersebut, dapat memberikan ruang kepada peserta pemilu maupun pihak lain untuk menyuruh seseorang menggunakan hak pilih orang lain dengan tujuan untuk mendapatkan keuntungan pribadi maupun agar terjadi Pemungutan Suara Ulang.

\section{Daftar Pustaka}

\section{Buku}

Arif, Barda Nawawi, Masalah Penegakan Hukum dan Kebijakan Hukum Pidana dalam Penanggulangan Kejahatan, Jakarta: Kencana Media Group, 2007.

Chazawi, Adami, Percobaan dan Penyertaan dalam Hukum Pidana (Pelajaran Hukum Pidana Bagian 3), Jakarta: Raja Grafindo Persada, 1999.

Fajar, Mukti dan Yulianto Achmad, Dualisme Penelitian Hukum Normatif dan Empiris, Yogyakarta: Pustaka Pelajar, 2010.

Friedman, Lawrence M., American Law: An Introduction, Second Edition, Penerjemah: Wishnu Basuki, Jakarta: PT. Tatanusa, 2001.

Hamzah, Andi, Hukum Pidana Indonesia \& Perkembangannya, Jakarta: PT Sofmedia, 2015.

Muladi, Mahmud dan Ferri Antoni Surbakti, Politik Hukum Pidana Terhadap Kejahatan Koporasi, Jakarta: Soft Media, 2010.

Santoso, Topo, Tindak Pidana Pemilu, Jakarta: Sinar Grafika, 2006.

\section{Jurnal dan Makalah}

Bambang, Sarah, Sri Setyadji dan Aref Darmawan, "Penanganan Tindak Pidana Pemilu dalam Sentra Penegakkan Hukum Terpadu (Gakkumdu)", Jurnal Indonesia Sosial Teknologi, Vol. 2, No. 2, Februari 2021.

Ersan, Paramita dan Anna Erliyana, “Kualifikasi Hukum Pidana Khusus Terhadap Tindak Pidana Pemilu/Pilkada (Tinjauan Hukum Administrasi Negara)“, Pakuan Law Review, Volume IV, Nomor 1, Januari-Juni 2018.

Fahmi, Khairul, "Sistem Penanganan Tindak Pidana Pemilu", Jurnal Konstitusi, Volume 12, Nomor 2, Juni 2015.

Nainggolan, Ibrahim, "Pertanggungjawaban Pidana Perbuatan Penggunaan Merek yang Sama pada Pokoknya Tanpa Izin (Analisis Putusan MA.RI No. 203/Pid.Sus/2015)", Jurnal EduTech, Volume 5, Nomor 1, Maret 2019. 


\section{Situs Web}

Mahesa, Desmond J., "Mengurai Belantara Penegakan Hukum Pidana Pemilu di Indonesia", LawJustice.com, https://www.law-justice.co/artikel/77571/mengurai-belantarapenegakan-hukum-pidana-pemilu-di-indonesia/, diakses pada tanggal 23 Februari 2021.

Ridhanie, Azhar, "Strategi Pengawas Pemilu dalam Menangani Tindak Pidana Pemilu: Implementasi Hukum Progresif dan Penerapan Pasal 55 KUHP dalam Penanganan Perkara Pidana di Kalimantan Selatan", Bawaslu Kalimantan Selatan, http://kalsel.bawaslu.go.id/elibrary/strategi-pengawas-pemilu-dalam-menanganitindak-pidana-pemilu/, diakses pada tanggal 23 Februari 2021. 